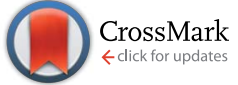

Cite this: J. Mater. Chem. A, 2015, 3 , 7273

Received 19th September 2014 Accepted 5th February 2015

DOI: $10.1039 / c 4 t a 04956 j$

www.rsc.org/MaterialsA

\section{High electron affinity: a guiding criterion for voltage stabilizer design $\uparrow$}

\author{
Markus Jarvid, ${ }^{a}$ Anette Johansson, ${ }^{\mathrm{b}}$ Villgot Englund, ${ }^{\mathrm{c}}$ Angelica Lundin, ${ }^{\mathrm{a}}$ \\ Stanislaw Gubanski, ${ }^{b}$ Christian Müller*a and Mats R. Andersson*ad
}

\begin{abstract}
Voltage stabilizers are an emerging class of additives that enhance the dielectric strength of an insulating polymer such as polyethylene. Several partially conflicting reports ascribe the stabilizing effect to either a high electron affinity or low ionization potential of the additive. Here, we report a clear correlation of the electron affinity and to a lesser extent the $E_{\mathrm{HOMO}}-E_{\mathrm{LUMO}}$ difference of various voltage stabilizers with electrical tree initiation in cross-linked polyethylene. To facilitate a fair evaluation, the voltage-stabilizing efficiency of a set of 13 previously reported voltage stabilizers, which strongly differ in their chemical composition, is compared at equal stabilizer concentration and equivalent test methodology. These results are correlated with the electron affinity and $E_{\mathrm{HOMO}}-E_{\mathrm{LUMO}}$ difference, as obtained from density functional theory (DFT) modeling, which agreed well with available literature values. Moreover, based on the here established strong correlation between dielectric strength and electron affinity, a new molecule with exceptionally high electron affinity is selected from the extended literature on organic photovoltaics. This malononitrile-benzothiadiazole-triarylamine based molecule with a high electron affinity of $3.4 \mathrm{eV}$ gives rise to a $148 \%$ increase in tree initiation field compared to $40 \%$ obtained using anthracene, one of the most efficient previously reported voltage-stabilizers, under equivalent test conditions. Thus, we here propose to use the electron affinity as a guiding criterion for identifying novel high-efficiency voltage stabilizers, which opens up the vast library of organic semiconductors as potential candidates, as well as associated synthesis routines for the design of yet unexplored materials.
\end{abstract}

\section{Introduction}

The pre-breakdown degradation phenomenon known as electrical treeing initiates at points of high and divergent electric field and is associated with insulation failure in power cables. Improvement of insulation materials becomes increasingly important with the introduction of green energy sources at remote locations, such as wind farms, where the requirement for efficient means of electrical power transport puts high demand on the high voltage cables used for this purpose. The design electric field of high voltage insulation materials is steadily increasing thanks to advances in physical cleanliness of the insulation material, which is usually cross-linked polyethylene (XLPE). ${ }^{1}$ Suitable additive systems using so-called voltage stabilizers have been known to

${ }^{a}$ Department of Chemical and Biological Engineering, Chalmers University of Technology, 51296 Göteborg, Sweden.E-mail: christian.muller@chalmers.se

${ }^{b}$ Department of Materials and Manufacturing Technology/High Voltage Engineering, Chalmers University of Technology, 51296 Göteborg, Sweden

'Innovation \& Technology, Borealis AB, 44486 Stenungsund, Sweden

${ }^{d}$ Ian Wark Research Institute, University of South Australia, Mawson Lakes, South Australia 5095, Australia.E-mail: mats.andersson@unisa.edu.au

$\dagger$ Electronic supplementary information (ESI) available. See DOI: $10.1039 / \mathrm{c} 4 \mathrm{ta} 04956 \mathrm{j}$ provide additional benefit by increasing the electric field for the onset of electrical treeing. ${ }^{2,3}$ The molal efficiency of these stabilizers has previously been correlated with a low ionization potential (IP) for certain groups of molecules including fused aromatics and benzophenones. ${ }^{4,5}$ It has been argued that this does not hold outside of these groups of molecules ${ }^{6}$ and it is seen from the work of Yamano et al. ${ }^{3}$ and Person et al. ${ }^{6}$ that a strongly non-linear concentration dependence can make this type of analysis difficult. Additionally, it has been proposed that a low excitation energy and high electron affinity (EA) are relevant parameters, especially for aromatic ketones. ${ }^{7,8}$

The modeling of molecular orbital energy levels is becoming increasingly relevant and is now an important tool in several fields of research. Phenomenological observations can help to select promising materials as well as provide foundation for deeper physico-chemical understanding. An example from the recent literature is the work of Nonoguchi et al. ${ }^{9}$ where DFT modeled $E_{\text {Hомо }}$ levels of molecular dopants could be correlated with the Seebeck coefficient for single walled carbon nanotubes. Similarly, the $E_{\mathrm{HOMO}}-E_{\mathrm{LUMO}}$ gap has been correlated with the open-circuit voltage of organic solar cells ${ }^{\mathbf{1 0}}$ and the $E_{\text {LUMO }}$ level of organic semiconductors can be used to estimate oxidation stability. ${ }^{\mathbf{1 1}}$ This theoretical approach allows tailoring of 
Table 1 Electronic properties for molecules relevant for voltage stabilization calculated using DFT B3LYP/6-311+G(d,p). Adiabatic and vertical ionization potentials, $\mathrm{IP}_{a}$ and $\mathrm{IP}_{v}$, adiabatic and vertical electron affinities, $\mathrm{EA}_{a}$ and $\mathrm{EA}_{v}$, and frontier molecular orbitals, $E_{\mathrm{HO} O \mathrm{MO}}$ and $E_{\mathrm{LUMO}}$ are given in $\mathrm{eV}$. $\Phi$ reference indicates the literature reference for the electrical tree initiation data on which the calculation of $\Phi$ has been based

\begin{tabular}{lllllll}
\hline Mol. nr. $\Phi$ ref. $\quad$ Mol. structure & $\mathrm{IP}_{a}$ & $\mathrm{IP}_{v}$ & $\mathrm{EA}_{a}$ & $\mathrm{EA}_{v}$ & $E_{\mathrm{HOMO}}$ & $E_{\mathrm{LOMO}}$
\end{tabular}<smiles>COc1ccc(C(=O)c2ccc(OC)cc2)cc1</smiles>

$\mathrm{IP}_{a}-\mathrm{IP}_{v} \quad \mathrm{EA}_{a}$

$\begin{array}{llllll}7.71 & 7.83 & 1.40 & 0.92 & -6.46 & -2.24\end{array}$

8.02

8.25

1.75

1.41

$\begin{array}{ll}E_{\text {HOMO }} & E_{\text {LUMO }} \\ \text { and } E_{\text {LUMO }} \text { are given } \\ \text { been based }\end{array}$

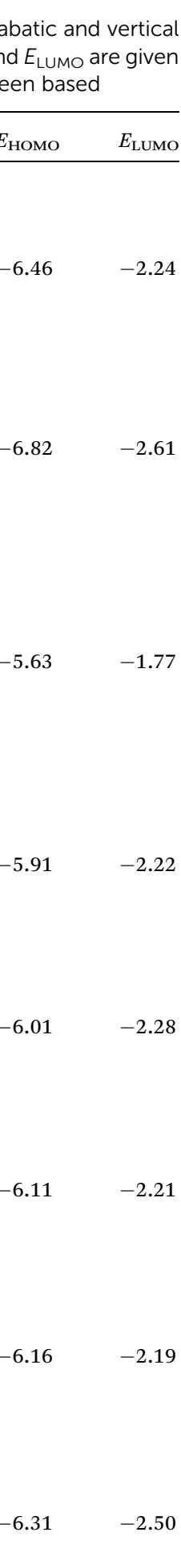

3

2<smiles>CC=CC(=O)C(=Cc1ccc(OC(C)=O)cc1)C(=O)O</smiles>

6.82

6.83

1.13

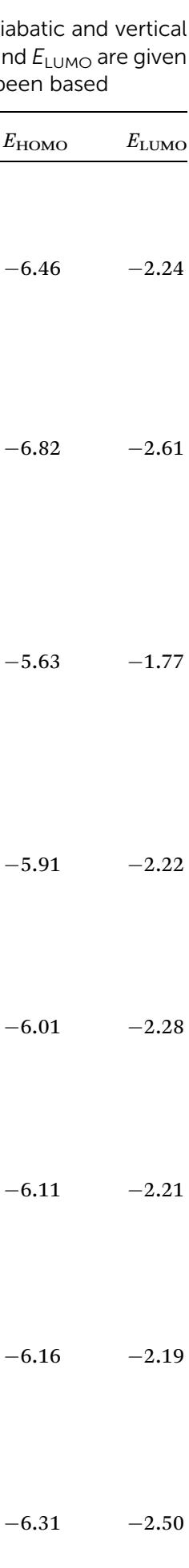

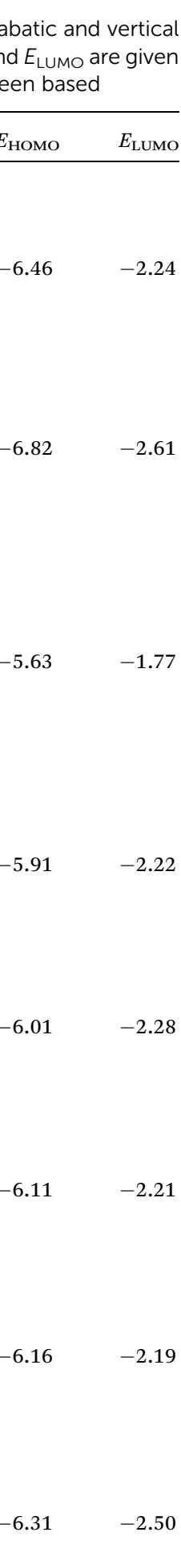

4

8<smiles>COc1ccc2sc3ccccc3c(=O)c2c1</smiles>

7.34

7.45

0.96

0.82

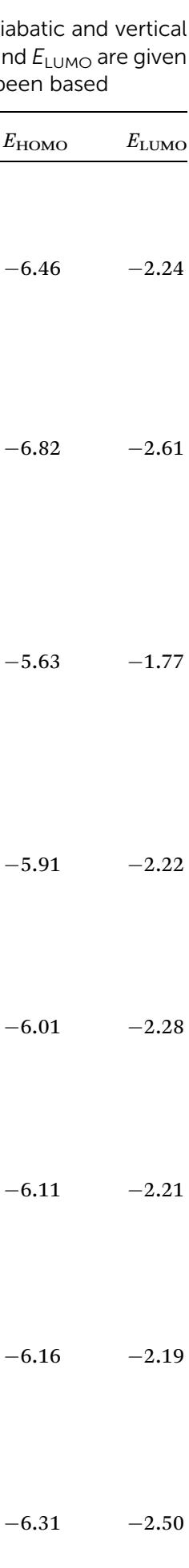

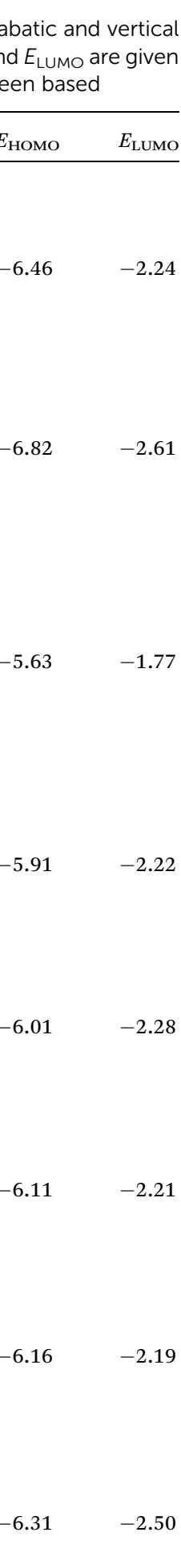

8<smiles>O=c1c2ccccc2sc2ccc(O)cc12</smiles>

7.49

7.59

1.00

0.86

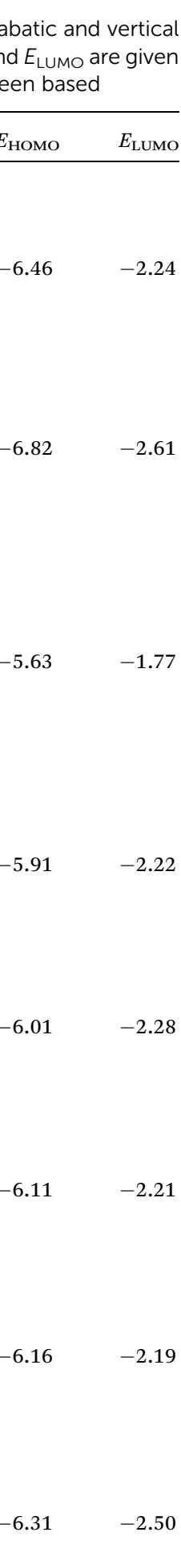<smiles>CC(C)c1ccc2sc3ccccc3c(=O)c2c1</smiles>

7.56

7.61

0.95

0.85

7<smiles>CC(C)c1cccc2c(=O)c3ccccc3sc12</smiles>

7.61

7.66

0.94

0.84

$\begin{array}{ll} & \\ E_{\text {HOMO }} & E_{\text {LUMO }} \\ \text { and } E_{\text {LUMO }} \text { are given } \\ \text { been based }\end{array}$

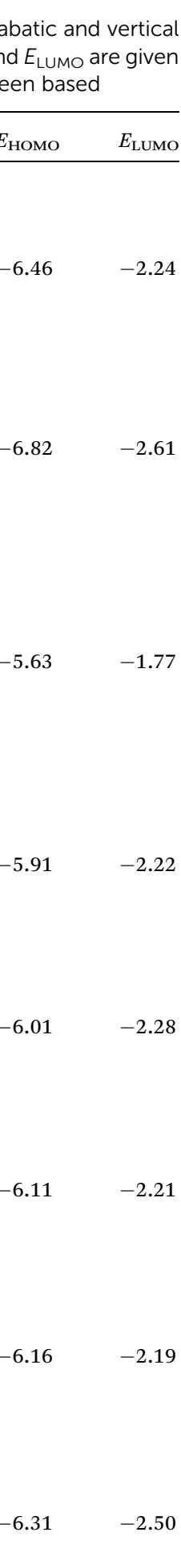

8

8<smiles>C=C(C)C(=O)OC1=CC2C(=O)c3ccccc3SC2C=C1</smiles>

8
7.42

7.95

1.31

1.18

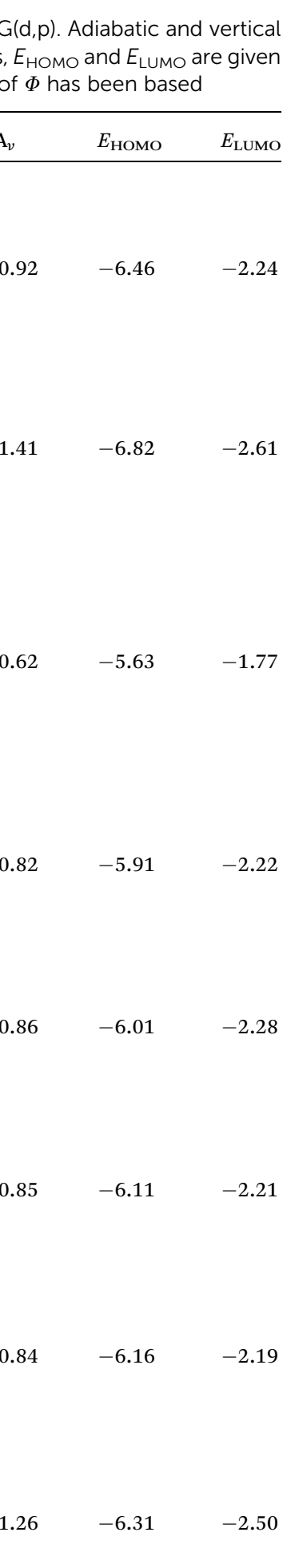

1.33

1.26

9 
Table 1 (Contd.)

Mol. ni.

Mol. nr. $\Phi$ ref.

Mol. structure

$\mathrm{IP}_{a}$

$\mathrm{IP}_{v}$

$\mathrm{EA}_{a}$

$\mathrm{EA}_{v}$

$E_{\text {HOMO }}$

$E_{\text {LUMO }}$

10

8<smiles>CCN(CC)c1nc(N(CC)CC)nc(N(CC)CC)n1</smiles>

7.18

7.19

$-0.69$

$-0.70$

$-5.85$

$-0.05$

11

8<smiles>CC(C)(C)c1ccc(Nc2ccc(C(C)(C)C)cc2)cc1</smiles>

12

8<smiles>CCN(CC)c1nc([NH-])nc(N(CC)CC)n1</smiles>

6.49

$-0.21-$

$\begin{array}{ll}-5.52 & -0.57\end{array}$

13<smiles>CN1c2ccccc2Sc2ccccc21</smiles>

6.66

6.9

$-0.37$

$-0.46$

$\begin{array}{ll}-5.35 & -0.76\end{array}$

14

18<smiles>Cc1ccc(N(c2ccc(C)cc2)c2ccc(-c3ccc(C=C(C#N)C#N)c4nsnc34)cc2)cc1</smiles>

6.42

6.62

3.44

2.94

$-5.61$

$-4.08$<smiles>CCN(CC)c1ccc(C(=O)c2ccccc2)cc1</smiles>

4, 20<smiles>c1ccc2cc3ccccc3cc2c1</smiles>

7.11

7.18

0.72

0.62

$-5.55$

$-2.01$

16<smiles>CC(=O)c1ccccc1</smiles>

$8.91 \quad 9.04$

0.43

0.24

$-7.10$

$-1.90$

17

21<smiles>O=C(c1ccccc1)c1ccccc1</smiles>

$8.49-$

0.83

$-$

$-6.99$

$-2.10$

18

21<smiles>O=C(c1ccccc1)c1ccc(O[GaH])cc1O</smiles>

7.74

0.97

$-6.34$

2.01 
Table 1 (Contd.)

Mol. nr. $\quad \Phi$ ref. $\quad$ Mol. structure

19

18, 21

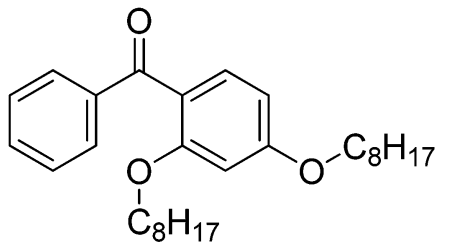<smiles>CCOc1ccc(C(=O)c2ccccc2)c(OCC)c1</smiles>

21<smiles>CCCCCCOc1ccc(C(=O)c2ccccc2)cc1</smiles>

22<smiles>CCN(CC)c1ccc(C(=O)c2ccc(N(CC)CC)cc2)cc1</smiles><smiles>CC(C)(C)c1ccc(C(=O)c2ccc(C(C)(C)C)cc2)cc1</smiles>

24

4

25

26

27

28
18

4

4

4

21

21<smiles>c1ccc2ccccc2c1</smiles><smiles>C1=Cc2cccc3cccc1c23</smiles><smiles>c1ccc2c(c1)ccc1ccccc12</smiles><smiles>c1ccc2c(c1)ccc1c3ccccc3ccc21</smiles><smiles>CCC</smiles>

$\mathrm{IP}_{a}$

$\mathrm{IP}_{v}$

7.22

7.40

7.68

0.52

0.34

$-6.12$

$7.79-$

0.68

$-$

$-6.45 \quad-1.85$

6.56

6.57

0.25

0.1

$-1.22$

0.7

8.02

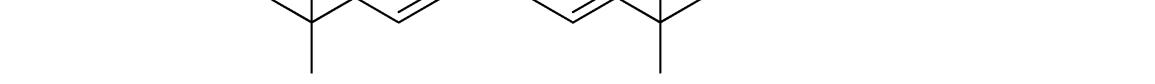

7.87

$-0.05$

$-0.18$

$-6.94$

$-1.39$

7.72

7.87

0.87

0.7

$-6.15$

$-2.29$<smiles>c1cc2ccc3cccc4ccc(c1)c2c34</smiles>

7.15

7.22

0.60

0.4

$-5.66$

$-1.85$

\footnotetext{
(2)
} 
Table 1 (Contd.)

Mol. nr. $\Phi$ ref. $\quad$ Mol. structure

29

4

30

4

31

18

32

18

33

22

34

22

35

18<smiles>CCOc1ccc(-c2ccc3c(c2)c2cc(-c4ccc(OCC)cc4)ccc2n3CC)cc1</smiles><smiles>c1ccc(-c2ccccc2-c2ccccc2)cc1</smiles><smiles>C=C(/C=C/CC)N(CC)CC</smiles>

$\mathrm{IP}_{a}$

IP

7.56

7.58

0.89

0.75

$-6.10$

$-2.15$

7.67

$-0.02$

$-6.26$

$-1.12$

6.60

6.76

0.79

0.68

$-5.31$

$-1.99$

6.40

6.73

0.06

$-0.18$

$-5.28$

$-1.12$

7.15

7.19

$-0.12$

$-0.23$

$-5.63$

$-1.12$

7.49

7.03

$-0.20$

$-0.46$

$-5.39$

$-0.87$

6.27

6.34

0.13

0.04

$-5.22$

$-1.09$ 
Table 1 (Contd.)

Mol. nr. $\Phi$ ref. $\quad$ Mol. structure

36

19

37

19

38

23

39

23

40

23<smiles>CCCCOc1ccc(-c2nc(-c3ccc(C)cc3C)nc(-c3ccc(C)cc3C)n2)c(O)c1</smiles><smiles>CCN(c1nc(N2CCOCC2)nc(N(CC)C2CC(C)(C)NC(C)(C)C2)n1)C1CC(C)(C)NC(C)(C)C1</smiles><smiles>Cc1ccc2c(c1)-c1c3ccccc3cc3c(C)ccc(c13)O2</smiles><smiles>Cc1ccc(/N=N/c2c(O)ccc3ccccc23)c(C)c1</smiles><smiles>INc1cccc2ccccc12</smiles><smiles>N=Nc1ccc(N=Nc2ccccc2)cc1</smiles><smiles>CNc1cccc2ccccc12</smiles>

41

23
$\mathrm{IP}_{a}$

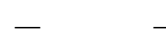

一

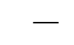

$-6.18$

$-1.74$

$-$

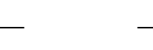

-

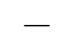

$-$

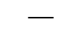

$-5.96$

$-0.22$

$\begin{array}{llllll}6.32 & 6.41 & 1.02 & 0.92 & -5.03 & -2.12\end{array}$

$\begin{array}{llllll}6.67 & 6.95 & 1.27 & 1.08 & -5.61 & -2.29\end{array}$

6.98

7.19

2.13

1.99

$-6.04$

$-3.05$<smiles>CI=Nc1cc(C)c(N=Nc2ccccc2C)cc1C</smiles>

6.93

2.08

1.9

$-2.94$ 
Table 1 (Contd.)

Mol. nr. $\Phi$ ref. $\quad$ Mol. structure

42

23

43

23

23

45

24<smiles>CCNC1=CC=C(O)C2C(=O)c3ccccc3C(=O)C12</smiles><smiles>Cc1ccc(C)cc1</smiles><smiles>CN(C)c1ccc(N=Nc2ccccc2)cc1</smiles><smiles>CCN(CC)c1ccc(N=Nc2ccccc2)cc1</smiles><smiles>O=[N+]([O-])c1ccccc1-c1ccccc1</smiles>

46

24<smiles>Nc1ccccc1[N+](=O)[O-]</smiles>

47

24<smiles>Cc1ccc([N+](=O)[O-])cc1[N+](=O)[O-]</smiles>

48

24

49

4

50

24<smiles>O=[N+]([O-])c1ccccc1F</smiles>

$\mathrm{IP}_{a}$

$\mathrm{IP}_{v}$

6.78

6.91

1.83

1.68

$-5.55$

$-2.88$

6.72

6.84

1.09

0.83

$-5.42-2.10$

8.40

1.35

$-6.97$

$-2.61$

8.27

1.15

$-6.48$

$-2.67$

9.88

1.97

$-8.44$

$-3.37$

9.68

1.40

$-7.89$

$-2.94$

8.66

1.04

$-6.97$

2.48

9.83

1.92

$\begin{array}{ll}-8.25 & -3.24\end{array}$ 
Table 1 (Contd.)

Mol. nr. $\Phi$ ref. $\quad$ Mol. structure

molecular electronic properties, allowing for more accurate design of new materials. For electrical breakdown in gasses it is well known that a high electron affinity of the gaseous medium increases the breakdown field by trapping of electrons, which delays the formation of electron avalanches. ${ }^{12}$ High electron affinity additives have also proven effective in increasing the breakdown strength of LDPE films. ${ }^{13}$

In this work, the electrical tree initiation in materials that contain a broad selection of previously reported voltage stabilizers has been correlated with DFT modeled energy levels of the frontier orbitals as well as the ionization potential and electron affinity of the stabilizer molecules. Due to the data scattering imposed by the use of different test methods, variations in polymer matrix materials, and a non-linear stabilizer concentration dependence, a more refined study was carried out where only comparable treeing data was used. This data set was expanded with an additional compound that was identified from DFT modeling as having a significantly higher electron affinity and a small $E_{\text {Номо }}-E_{\text {LUMO }}$ difference. Additionally, two reference compounds that previously have been reported as efficient voltage stabilizers were investigated in the same manner.

\section{Results and discussion}

IPs, EAs and frontier molecular orbitals were calculated using DFT modeling ( $c f$. Experimental section) for a wide range of molecules for which data on electrical tree initiation is available in the literature (Table 1). IP and EA can be given as vertical or adiabatic depending on the geometry of the charged state, i.e. if it is optimized to minimum energy (adiabatic) or if it is frozen in the optimized neutral ground state configuration (vertical). The IPs, and the EAs are defined by and obtained using the following formulas:

$$
\begin{gathered}
\mathrm{IP}_{v}=E^{+}(M)-E(M) \approx-E_{\mathrm{HOMO}} \\
\mathrm{IP}_{a}=E^{+}\left(M^{+}\right)-E(M) \\
\mathrm{EA}_{v}=E(M)-E^{-}(M) \approx-E_{\mathrm{LUMO}} \\
\mathrm{EA}_{a}=E(M)-E^{-}\left(M^{-}\right)
\end{gathered}
$$

where $E^{+}\left(M^{+}\right), E^{-}\left(M^{-}\right)$, and $E(M)$ represent the energies of the cation, anion, and neutral species in their optimized geometries, respectively, while $E^{+}(M)$ represents the energy of the cation with the geometry of the neutral molecule and $E^{-}(M)$ represents the energy of the anion with the geometry of the neutral molecule. The vertical energy, $v$, is based on the geometry of the neutral molecule while $a$ represents instead the adiabatic energy from the optimized structures for both the neutral and charged molecule. $\mathrm{IP}_{v}$ and $\mathrm{EA}_{v}$ are according to Koopman's theorem approximately equal to $-E_{\text {номо }}$ and $-E_{\mathrm{LUMO}}$, respectively. We find that both $\mathrm{IP}_{v}$ and $\mathrm{IP}_{a}$ roughly correlate with $E_{\mathrm{HOMO}}$ and a similar correlation is seen for both $\mathrm{EA}_{v}$ and $\mathrm{EA}_{a}$ with $E_{\mathrm{LUMO}}(c f$. SI $\dagger)$. The relation between $\mathrm{IP}_{v}, \mathrm{IP}_{a}$, $\mathrm{EA}_{v}$ and $\mathrm{EA}_{a}$ is further illustrated in Fig. 1. 


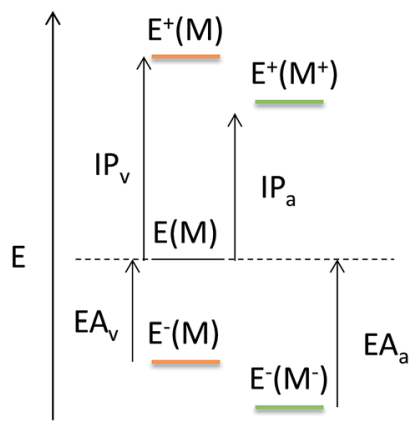

Fig. 1 Adiabatic ionization potential $I P_{a}$, vertical ionization potential $I P_{v}$, adiabatic electron affinity $E A_{a}$, and vertical electron affinity $E A_{v}$ visualized using molecular energies. $E(M)$ represents the neutral ground state while $E^{+}(M)$ and $E^{-}(M)$ represent the cation and anion with neutral ground state geometry. $E^{+}\left(M^{+}\right)$and $E^{-}\left(M^{-}\right)$represent the cation and the anion with optimized geometry.

The increase in electrical tree initiation field obtained when incorporating voltage stabilizers in XLPE can be described by the parameter $\Phi$

$$
\Phi=\frac{\left(E_{63}-E_{63}^{\mathrm{XLPE}}\right)}{E_{63}^{\mathrm{XLPE}}} \times \frac{1}{c}
$$

where $E_{63}$ and $E_{63}^{\mathrm{XLPE}}$ are the $63 \%$ probability percentiles from the Weibull distribution fitted to the electrical tree initiation data sets of stabilized and reference XLPE, respectively, and $c$ is the molal concentration of the stabilizer. ${ }^{\mathbf{1 4}}$ The $E_{63}$ values are analogous to the mean of a Gaussian distribution. $\Phi$ was calculated for the compounds 1-56 presented in Tables 1 and 2 . In the cases where Weibull statistics had not been used, $E_{63}$ and $E_{63}^{\mathrm{XLPE}}$ were replaced with average tree initiation voltage or electric field for the voltage stabilized material and the reference material, respectively. The reference material used in the literature sources was either LDPE or XLPE.

As shown in Fig. 2 (grey symbols), $\Phi$ was plotted against (a). $\mathrm{IP}_{a}$, (b). $\mathrm{EA}_{a}$ and (c). $E_{\mathrm{HOMO}}-E_{\mathrm{LUMO}}$. It becomes apparent that the data scattering prevents us from drawing reliable conclusions. Weak correlations can nevertheless be seen indicating that a high electron affinity and a small $E_{\text {Номо }}-E_{\text {LUMO }}$ difference are beneficial attributes for the voltage stabilizing efficiency. Alkyl chain substituents in the experimentally tested stabilizers are replaced with ethyl groups in the DFT calculations, where needed, to circumvent convergence issues. The error introduced is exemplified by molecules 19 and 20 where 19 carries the full length octyl chains while $\mathbf{2 0}$ only features ethyl chains. In this case the error is within $0.2 \mathrm{eV}$ for all reported energies.

A series of data points previously reported by Jarvid et al. ${ }^{2}$ and Wutzel et al. ${ }^{\mathbf{8}}$ ( $c f$. Table 1, 1-12) are highlighted with open red circles in Fig. 2. For these compounds, the voltage stabilizing efficiency in XLPE has been measured under comparable conditions, i.e. the same sample preparation, molal stabilizer concentration (10 mmol kg ${ }^{-1}$ ), base polymer matrix and electrical test method has been applied. Further details on electrical treeing experiments can be found in ref. 2, 8, 15 and 16 and the 3-parameter Weibull statistics are summarized in Table 3.

Additionally, three new compounds ( $c f$. Table 1, 13-15) were measured as part of this work using the same measurement setup and a similar sample preparation except that a special diffusion technique was employed for two of the compounds ( $c f$. Experimental section). The substance, known as DTDCPB ( $c f$. Table 1, 13), was originally synthesized for the purpose of small molecule organic photovoltaics by Chen et al. ${ }^{17}$ and was here used to expand our data set to a wider range of molecular properties after being identified as a suitable candidate by DFT calculations. In a first experiment this compound was shown to degrade during cross-linking as indicated by a color change from blue to yellow. To prevent this, the compound was added after cross-linking by means of diffusion at elevated temperature. Two additional substances, $N, N$-dioctylamino benzophenone $^{18}$ and anthracene ${ }^{3,4}$ (Table $\left.1,14,15\right)$, were chosen from previous voltage stabilizer literature to act as references. Anthracene was also not compatible with the cross-linking process and was added by diffusion after cross-linking similarly to DTDCPB. 3-parameter Weibull statistics are presented in Table 3. Details on the statistical data analysis can be found in ref. 2 ( $c f$. SI- $1 \dagger$ for cumulative Weibull distributions).

This smaller set of data points including 1-15, indicated in Fig. 2 with red circles, shows that EA has a good correlation with $\Phi$, with only one small exception in this series. The $E_{\mathrm{HOMO}^{-}}$

Table 2 Experimental ionization potential (IP exp $)$, electron affinity $\left(\mathrm{EA}_{\mathrm{exp}}\right)$ and $E_{\mathrm{HOMO}}-E_{\mathrm{LUMO}}$ in eV for fullerenes

Mol. nr. Mol. structure $\quad \mathrm{IP}_{\exp } \quad \mathrm{EA}_{\exp } \quad E_{\mathrm{HOMO}}-E_{\mathrm{LUMO}}(\exp )$
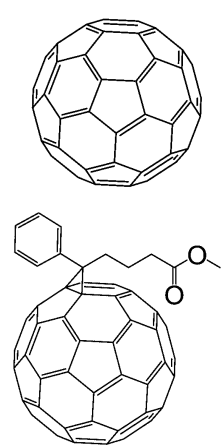
a

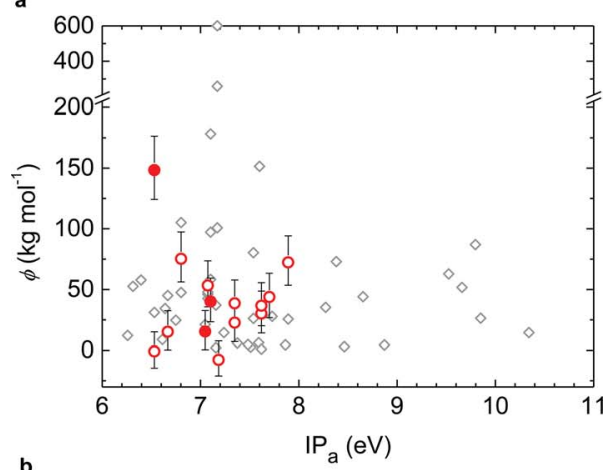

b

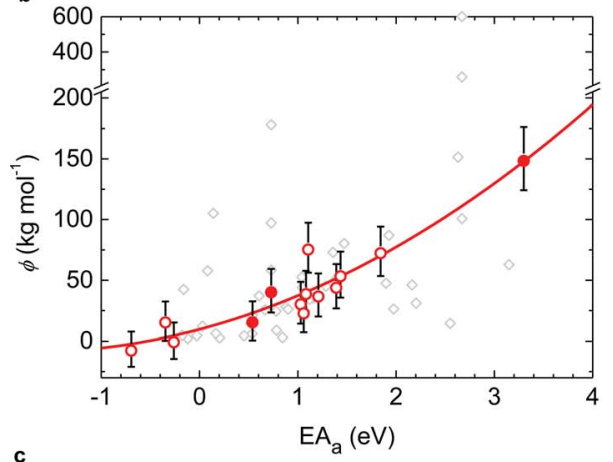

c

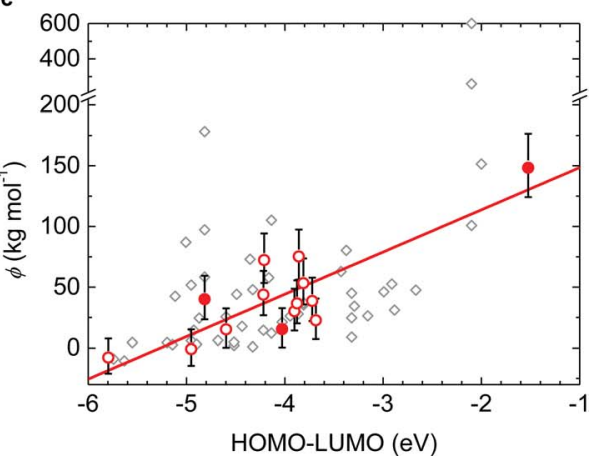

method in computational physics and chemistry. ${ }^{30}$ B3LYP is a hybrid functional, which was originally developed using experimental correlations with, among other things, IP and EA and is a commonly used, robust and cheap method for this purpose. This method together with the basis set used, 6-311+G(d,p) has proven reliable in the previous literature. ${ }^{31,32}$ To further confirm the validity of the calculation method, the calculated data is compared with corresponding previously reported experimental values for a subset of the data ( $c f$. Table 3 ). The data scales with experimental data but a slight offset is observed. $\mathrm{IP}_{a}$ is on average underestimated by $\sim 0.3 \mathrm{eV}$ and $\mathrm{EA}_{a}$ is on average overestimated by $\sim 0.3$ $\mathrm{eV}$ ( $c f$. Fig. 3a and b respectively).

\section{Experimental section}

\section{DFT calculations}

The equilibrium geometries of all the stationary points of the neutral and ionic states of the studied molecules at their ground states are fully optimized using the density functional theory (DFT) method at the B3LYP/6-311+G(d,p) level of theory ${ }^{47-49}$ using the GAUSSIAN09 program package. ${ }^{50}$ Calculated harmonic vibrational frequencies are confirmed by normalmode analysis to have real frequencies corresponding to all of the vibrating modes. All calculated molecular energies are enthalpy corrected for $298 \mathrm{~K}$ and $1 \mathrm{~atm}$.

\section{Materials}

2-([7-(4-N,N-ditolylaminophenylen-1-yl)-2,1,3-benzothiadiazol-4-yl] methylene)malononitrile (DTDCPB), 97\% purity (HPLC), and anthracene (99\% purity) were used as purchased from Sigma Aldrich. $N, N$-dioctylamino benzophenone (DOABP) was synthesized in our lab according to procedure reported in ref.

Fig. 2 (a) Adiabatic ionization potential $I P_{a}$, (b) adiabatic electron affinity $\mathrm{EA}_{a}$ and (c) $E_{\mathrm{HOMO}}-E_{\mathrm{LUMO}}$ plotted against voltage stabilizing efficiency $\Phi$. Red symbols indicate that electrical treeing tests have been performed using the same test object geometry, stabilizer concentration $\left(10 \mathrm{mmol} \mathrm{kg}{ }^{-1}\right)$ and electrical test method. Filled circles are data reported for the first time in this publication. The red lines are empirical fits to the red data points (2nd order polynomial in b and linear in C). $\mathrm{C}_{60}$ fullerene and PCBM are included (filled diamonds) using experimental values for IP, EA and $E_{\text {HOMO }}-E_{\text {LUMO }}$ (cf. Table 2). $\Phi$ was calculated using electrical tree initiation data as indicated in Table 1 and from ref. 14 in the case of fullerenes.

$E_{\text {LUMO }}$ band gap has a weaker correlation with $\Phi$ while the IP is largely unrelated to $\Phi$ for this data set. For large molecules e.g. mol. nr. 36-37 it can be convenient to use $-E_{\mathrm{LUMO}}$ as an indication of relative $\mathrm{EA}$, or $-E_{\mathrm{HOMO}}$ for IP, as they are roughly linearly correlated ( $c f$. SI- $2 \dagger)$. The fact that 36 has a voltage stabilizing effect while 37 does not ${ }^{19}$ can be explained by the difference in $E_{\text {LUMO }}$.

\section{Calculation method verification}

DFT has become more and more widely used over the last 50 years and is now the most popular computational electronic structure

Table 3 Weibull fit parameters for electrical treeing measurements of XLPE materials. Number of trees included in the analysis $N$, threshold electrical field $E_{0}$, electrical field, at which $63 \%$ of all samples have failed, $E_{63}$ (analogous to the mean of the Gaussian distribution), and shape parameter $\beta$. Treeing data for mol. nr. 1-3 and 4-12 are from ref. 2 and 8 , respectively

\begin{tabular}{llrlr}
\hline XLPE + mol. nr. & $N(-)$ & $E_{0}\left(\mathrm{kV} \mathrm{m}^{-1}\right)$ & $E_{63}\left(\mathrm{kV} \mathrm{mm}^{-1}\right)$ & $\beta(-)$ \\
\hline- & 56 & 248 & 296 & 1.6 \\
$\mathbf{1}$ & 32 & 232 & 425 & 5.3 \\
$\mathbf{2}$ & 20 & 263 & 509 & 4.0 \\
$\mathbf{3}$ & 28 & 0 & 513 & 7.3 \\
$\mathbf{4}$ & 28 & 39 & 362 & 7.4 \\
$\mathbf{5}$ & 24 & 283 & 410 & 2.6 \\
$\mathbf{6}(80 \%)+7(20 \%)$ & 28 & 296 & 385 & 3.0 \\
$\mathbf{8}$ & 22 & 98 & 459 & 9.3 \\
$\mathbf{9}$ & 28 & 314 & 404 & 1.3 \\
$\mathbf{1 0}$ & 28 & 254 & 273 & 1.5 \\
$\mathbf{1 1}$ & 16 & 0 & 293 & 20.1 \\
$\mathbf{1 2}$ & 24 & 219 & 340 & 2.3 \\
$\mathbf{1 3}$ & $11+9^{a}$ & 289 & 734 & 2.5 \\
$\mathbf{1 4}$ & 32 & 271 & 341 & 2.7 \\
$\mathbf{1 5}$ & 24 & 336 & 414 & 1.3
\end{tabular}

${ }^{a}$ Right censored at $680 \mathrm{kV} \mathrm{mm}^{-1}$. 
Table 4 Experimental ionization potentials $\mathrm{IP}_{\exp }$ and electron affinities EA $\mathrm{A}_{\exp }$

Mol. nr.

12

15

17

24

25

26

28<smiles>CN1c2ccccc2Sc2ccccc21</smiles><smiles>c1ccc2cc3ccccc3cc2c1</smiles><smiles>O=C(c1ccccc1)c1ccccc1</smiles><smiles>c1ccc2ccccc2c1</smiles>

7.87<smiles></smiles><smiles>c1ccc2c(c1)ccc1ccccc12</smiles>

7.59<smiles>c1ccc2c(c1)ccc1c3ccccc3ccc21</smiles><smiles>c1cc2ccc3cccc4ccc(c1)c2c34</smiles>

7.15<smiles>c1ccc2c(c1)-c1cccc3cccc-2c13</smiles>

7.56<smiles>c1ccc(-c2ccccc2-c2ccccc2)cc1</smiles>

7.25

7.6 (ref. 16)

7.426 (ref. 16)

7.9 (ref. 16)

7.52

8.40

8.27

6.73 (ref. 33)

7.439 (ref. 16)

9.08 (ref. 16)

8.144 (ref. 16)

8.12 (ref. 16)

7.891 (ref. 16)

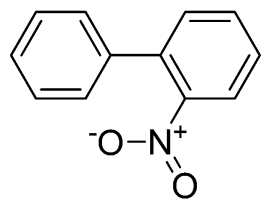

0.50

0.32 (ref. 37)

$\mathrm{EA}_{a}$

$-0.37$

0.72

0.53 (ref. 34)

0.83

0.655 (ref. 35)

-0.2 (ref. 36)

$-$

0.15

-

0.60

0.406 (ref. 38)

0.89

0.19

1.35

1.15

1.07 (ref. 39) 
Table 4 (Contd.)

\begin{tabular}{|c|c|c|c|c|c|}
\hline Mol. nr. & Mol. structure & $\mathrm{IP}_{a}$ & $\mathrm{IP}_{\exp }$ & $\mathrm{EA}_{a}$ & $\mathrm{EA}_{\exp }$ \\
\hline 46 & & 9.68 & 8.27 (ref. 40 ) & 1.40 & - \\
\hline 48 & & 8.66 & 9.86 (ref. 41) & 1.04 & 1.08 (ref. 42) \\
\hline 49 & & 9.83 & 8.8 (ref. 43) & 1.92 & - \\
\hline 50 & & 10.37 & - & 2.55 & 1.47 (ref. 44 ) \\
\hline 51 & & 9.55 & 10.59 (ref. 40 ) & 3.07 & - \\
\hline 53 & & 7.13 & 9.74 (ref. 45) & -0.30 & 2.78 (ref. 46 ) \\
\hline 54 & & 6.66 & 6.71 (ref. 16) & -0.37 & - \\
\hline
\end{tabular}

18. Cross-linkable LDPE compound with the trade name Borlink $^{\mathrm{TM}}$ LS4201S, containing dicumyl peroxide and the antioxidant 6,6'-di-tert-butyl-4,4'-thiodi- $m$-cresol, was obtained from Borealis AB (typical melt-flow index $\sim 2 \mathrm{~g} / 10 \mathrm{~min}$ at $190{ }^{\circ} \mathrm{C}$ and $2.16 \mathrm{~kg}$, density $\sim 0.922 \mathrm{~g} \mathrm{~cm}^{-3}$ ). This compound has a low level of contaminants that may influence electrical measurements and is recommended for use in high voltage applications up to $220 \mathrm{kV} .^{1}$

\section{Sample preparation}

DOABP stabilized samples were prepared according to the following procedure: peroxide containing LDPE pellets were ground to a fine powder with a Retsch grinder equipped with a 500 micrometer sieve. Subsequently, the powder was impregnated with a DOABP-dichloromethane solution $\left(1 \mathrm{ml} \mathrm{g}^{-1}\right.$ solvent with respect to LDPE). The solvent was removed by rotary evaporation followed by drying in vacuum to give a final stabilizer concentration of $10 \mathrm{mmol} \mathrm{kg}{ }^{-1}$. The impregnated LDPE compound was melt-pressed at $130{ }^{\circ} \mathrm{C}$ to form two separate parts, which were molded together to enclose a $10 \mu \mathrm{m}$ thin tungsten wire, followed by cross-linking of LDPE at $180{ }^{\circ} \mathrm{C}$ to form the final XLPE test object ( $c f$. ref. 51 for detailed description). Cross-linking by-products were removed by degassing samples in vacuum $(0.1 \mathrm{mbar})$ at $80{ }^{\circ} \mathrm{C}$ for 4 days. To ensure a comparable thermal history cross-linked and degassed samples were cooled from $130{ }^{\circ} \mathrm{C}$ at a rate of 0.2 to $0.5^{\circ} \mathrm{C} \mathrm{min}^{-1}$.

Samples stabilized with anthracene as well as samples stabilized with DTDCPB were prepared by diffusion-loading. 

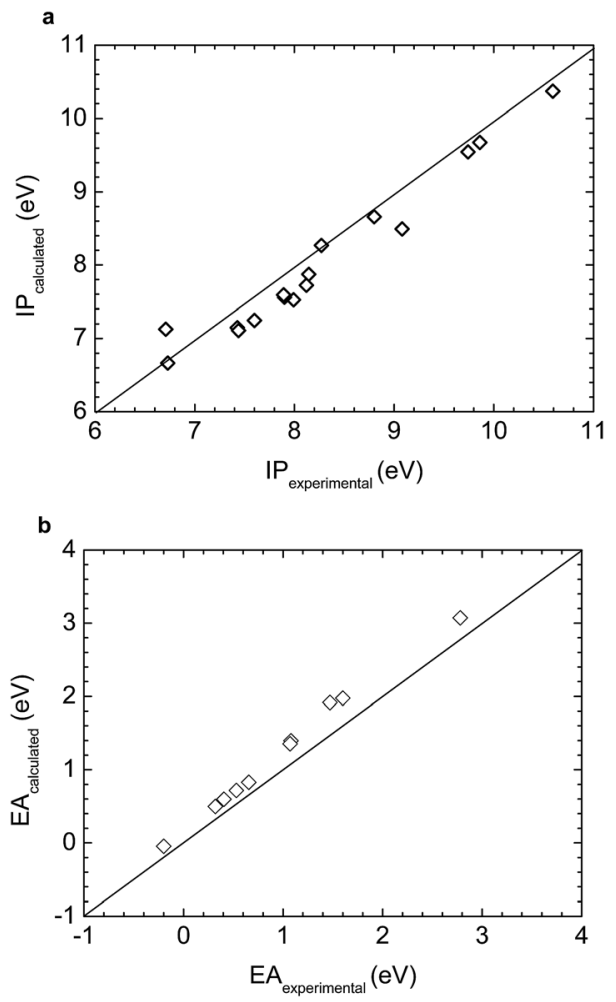

Fig. 3 DFT calculated (a) IP $a$ and (b) EA $A_{a}$ plotted against corresponding experimental data in Table 4. The line indicates $1: 1$ ratio.

This was done by deposition of solid stabilizer powder on XLPE test objects prepared as described above but without voltage stabilizer and was followed by heat treatment allowing the stabilizer to diffuse into the sample and homogenize. For anthracene this was done at $130{ }^{\circ} \mathrm{C}$ in a sealed glass container for $24 \mathrm{~h}$. For DTDCPB this was done by incrementally increasing the temperature from $140{ }^{\circ} \mathrm{C}$ to $180{ }^{\circ} \mathrm{C}$ during three days after which the temperature was held for six days until all the deposited stabilizer had diffused into the samples. DTDCPB diffusion was performed under nitrogen atmosphere. All samples were subjected to the same final heat treatment (cooling from $130{ }^{\circ} \mathrm{C}$ at a rate of 0.2 to $0.5^{\circ} \mathrm{C} \mathrm{min}{ }^{-1}$ ). The target concentration was $10 \mathrm{mmol} \mathrm{kg}^{-1}$. Deviations from the target concentration of up to $\sim 25 \%$ are estimated for the concentration of the diffusion loaded samples as controlled by weight measurements on the individual samples before and after addition and diffusion of voltage stabilizer.

\section{Conclusion}

We propose DFT calculated electron affinity $\mathrm{EA}_{a}$ as a guiding criterion for the identification of new efficient voltage stabilizers. The validity of this approach is confirmed through correlations with previously published data as well as new experimental data on electrical tree initiation. The results also indicate that a small $E_{\text {HOMO }}-E_{\text {LUMO }}$ difference is beneficial for achieving a high voltage stabilizer efficiency. Contrary to what has been reported for groups of similar voltage stabilizers, we observe no general trend correlating IP to stabilizer efficiency. The here proposed guiding criterion opens up the vast library of organic semiconductors as potential high-efficiency voltage stabilizers, as well as associated synthesis routines for the preparation of new additives. Good correlation between DFTcalculated IPs and EAs with existing experimental data was obtained with the employed calculation method; DFT B3LYP/6$311+\mathrm{G}(\mathrm{d}, \mathrm{p})$.

\section{Acknowledgements}

We thank the Chalmers Area of Advance Materials Science, the Chalmers Area of Advance Energy and Borealis AB for funding. $\mathrm{MJ}$ and $\mathrm{AJ}$ are supported by a twin PhD student project financed by the Chalmers Area of Advance Materials Science. The computations were performed on resources provided by the Swedish National Infrastructure for Computing (SNIC) at C3SE.

\section{References}

1 J. O. Boström, E. Marsden, R. N. Hampton and U. Nilsson, IEEE Electr. Insul. Mag., 2003, 19, 6-12.

2 M. Jarvid, A. Johansson, J. M. Bjuggren, H. Wutzel, V. Englund, S. Gubanski, C. Müller and M. R. Andersson, J. Polym. Sci., Part B: Polym. Phys., 2014, 52, 1047-1054.

3 Y. Yamano and M. Ilzuka, in Electr. Insul. Mater., 2008. (ISEIM 2008). Int. Symp., 2008, pp. 392-395.

4 A. C. Ashcraft, R. M. Eichhorn and R. G. Shaw, in IEEE Int. Symp. Electr. Insul., 1976, pp. 213-218.

5 V. Englund and T. Hjertberg, in Jicable 2011, Versailles, France, 2011.

6 T. Person and B. Neese, in Jicable 2011, Versailles, France, 2011.

7 H. Zhang, Y. Shang, X. Wang, H. Zhao, B. Han and Z. Li, J. Mol. Model., 2013, 19, 5429-5438.

8 H. Wutzel, M. Jarvid, J. M. Bjuggren, A. Johansson, V. Englund, S. Gubanski and M. R. Andersson, Pol. Deg. Stab., 2015, 112, 63-69.

9 Y. Nonoguchi, K. Ohashi, R. Kanazawa, K. Ashiba, K. Hata, T. Nakagawa, C. Adachi, T. Tanase and T. Kawai, Sci. Rep., 2013, 3, 3344 .

10 K. Vandewal, K. Tvingstedt, A. Gadisa, O. Inganas and J. V. Manca, Nat. Mater., 2009, 8, 904-909.

11 J. M. Ball, R. K. M. Bouwer, F. B. Kooistra, J. M. Frost, Y. Qi, E. B. Domingo, J. Smith, D. M. de Leeuw, J. C. Hummelen, J. Nelson, A. Kahn, N. Stingelin, D. D. C. Bradley and T. D. Anthopoulos, J. Appl. Phys., 2011, 110, 014506.

12 E. Kuffel, W. S. Zaengl and J. Kuffel, in High Voltage Engineering Fundamentals, ed. E. Kuffel, W. S. Zaengl and J. Kuffel, Newnes, Oxford, 2nd edn, 2000, pp. 281-366.

13 Y. Yamano, IEEE Trans. Dielectr. Electr. Insul., 2006, 13, 773781.

14 M. Jarvid, A. Johansson, R. Kroon, J. M. Bjuggren, H. Wutzel, V. Englund, S. Gubanski, M. R. Andersson and C. Müller, Adv. Mater., 2015, 27, 897-902. 
15 E. M. Jarvid, A. B. Johansson, J. H. M. Blennow, M. R. Andersson and S. M. Gubanski, IEEE Trans. Dielectr. Electr. Insul., 2013, 20, 1712-1719.

16 M. Jarvid, A. Johansson, V. Englund, S. Gubanski and M. R. Andersson, in Electr. Insul. Dielectr. Phen. (CEIDP), 2012 Ann. Rep. Conf., 2012, pp. 605-608.

17 Y.-H. Chen, L.-Y. Lin, C.-W. Lu, F. Lin, Z.-Y. Huang, H.-W. Lin, P.-H. Wang, Y.-H. Liu, K.-T. Wong, J. Wen, D. J. Miller and S. B. Darling, J. Am. Chem. Soc., 2012, 134, 13616-13623.

18 V. Englund, R. Huuva, S. M. Gubanski and T. Hjertberg, Polym. Degrad. Stab., 2009, 94, 823-833.

19 T. J. Person and J. M. Cogen,in WO2012050792 (A1), 2012.

20 Y. Yamano and M. Iizuka, IEEE Trans. Dielectr. Electr. Insul., 2009, 16, 189-198.

21 L. Martinotto, F. Peruzzotti and M. Del Brenna, in US2002164480 (A1), 2002.

22 V. Englund, R. Huuva, S. M. Gubanski and T. Hjertberg, IEEE Trans. Dielectr. Electr. Insul., 2009, 16, 1455-1461.

23 H. J. Davis, in US4216101 (A), Canada Wire \& Cable CO, 1980. 24 L. J. Heidt, in CA832524A, Simplex Wire \& Cable CO, 1970.

25 H. Kato and N. Maekawa, in US3956420 (A), Dainichi Nippon Cables LTD, 1976.

26 R. K. Yoo, B. Ruscic and J. Berkowitz, J. Chem. Phys., 1992, 96, 911-918.

27 C. Brink, L. H. Andersen, P. Hvelplund, D. Mathur and J. D. Voldstad, Chem. Phys. Lett., 1995, 233, 52-56.

28 K. Akaike, K. Kanai, H. Yoshida, J. y. Tsutsumi, T. Nishi, N. Sato, Y. Ouchi and K. Seki, J. Appl. Phys., 2008, 104, 023710.

29 B. W. Larson, J. B. Whitaker, X.-B. Wang, A. A. Popov, G. Rumbles, N. Kopidakis, S. H. Strauss and O. V. Boltalina, J. Phys. Chem. C, 2013, 117, 14958-14964.

30 A. D. Becke, J. Chem. Phys., 2014, 140, 18 A301.

31 C.-G. Zhan, J. A. Nichols and D. A. Dixon, J. Phys. Chem. A, 2003, 107, 4184-4195.

32 G. Zhang and C. B. Musgrave, J. Phys. Chem. A, 2007, 111, 1554-1561.

33 A. P. Poltorakov, F. N. Pirnazarova, P. G. But, L. A. Piruzyan, V. M. Chibrikin, Y. I. Vikhlyaev and O. V. Ul'yanova, Russ. Chem. Bull., 1973, 22, 2050-2053.

34 R. Huuva, V. Englund, S. M. Gubanski and T. Hjertberg, IEEE Trans. Dielectr. Electr. Insul., 2009, 16, 171-178.

35 C. Huh, C. H. Kang, H. W. Lee, H. Nakamura, M. Mishima, Y. Tsuno and H. Yamataka, Bull. Chem. Soc. Jpn., 1999, 72, 1083-1091.

36 S. A. Lyapustina, S. Xu, J. M. Nilles and K. H. Bowen, J. Chem. Phys., 2000, 112, 6643-6648.
37 K. E. Richards, B. N. McMaster and G. J. Wright, Org. Mass Spectrom., 1975, 10, 295-312.

38 N. Ando, S. Kokubo, M. Mitsui and A. Nakajima, Chem. Phys. Lett., 2004, 389, 279-283.

39 S. Chowdhury, H. Kishi, G. W. Dillow and P. Kebarle, Can. J. Chem., 1989, 67, 603-610.

40 V. K. K. Potapov, I. E. Kardash, V. V. Sorokin, S. A. Sokolov and T. I. Evlasheva, Khim. Vys. Energ., 1972, 6, 392.

41 M. H. Palmer, W. Moyes, M. Spiers, J. Neil and A. Ridyard, J. Mol. Struct., 1979, 55, 243-263.

42 S. Chowdhury, T. Heinis, E. P. Grimsrud and P. Kebarle, J. Phys. Chem., 1986, 90, 2747-2752.

43 T. Kobayashi and S. Nagakura, J. Electron Spectrosc. Relat. Phenom., 1975, 6, 421-427.

44 E. K. Fukuda and R. T. McIver, J. Am. Chem. Soc., 1985, 107, 2291-2296.

45 N. Sato, K. Seki and H. Inokuchi, J. Chem. Soc., Faraday Trans. 2, 1981, 77, 1621-1633.

46 T. Heinis, S. Chowdhury, S. L. Scott and P. Kebarle, J. Am. Chem. Soc., 1988, 110, 400-407.

47 A. D. Becke, J. Chem. Phys., 1993, 98, 5648-5652.

48 C. Lee, W. Yang and R. G. Parr, Phys. Rev. B: Condens. Matter Mater. Phys., 1988, 37, 785-789.

49 R. Krishnan, J. S. Binkley, R. Seeger and J. A. Pople, J. Chem. Phys., 1980, 72, 650-654.

50 M. J. Frisch, G. W. Trucks, H. B. Schlegel, G. E. Scuseria, M. A. Robb, J. R. Cheeseman, G. Scalmani, V. Barone, B. Mennucci, G. A. Petersson, H. Nakatsuji, M. Caricato, X. Li, H. P. Hratchian, A. F. Izmaylov, J. Bloino, G. Zheng, J. L. Sonnenberg, M. Hada, M. Ehara, K. Toyota, R. Fukuda, J. Hasegawa, M. Ishida, T. Nakajima, Y. Honda, O. Kitao, H. Nakai, T. Vreven, J. A. Montgomery Jr, J. E. Peralta, F. Ogliaro, M. J. Bearpark, J. Heyd, E. N. Brothers, K. N. Kudin, V. N. Staroverov, R. Kobayashi, J. Normand, K. Raghavachari, A. P. Rendell, J. C. Burant, S. S. Iyengar, J. Tomasi, M. Cossi, N. Rega, N. J. Millam, M. Klene, J. E. Knox, J. B. Cross, V. Bakken, C. Adamo, J. Jaramillo, R. Gomperts, R. E. Stratmann, O. Yazyev, A. J. Austin, R. Cammi, C. Pomelli, J. W. Ochterski, R. L. Martin, K. Morokuma, V. G. Zakrzewski, G. A. Voth, P. Salvador, J. J. Dannenberg, S. Dapprich, A. D. Daniels, Ö. Farkas, J. B. Foresman, J. V. Ortiz, J. Cioslowski and D. J. Fox, Gaussian 09, Gaussian, Inc., Wallingford, CT, USA, 2009.

51 E. M. Jarvid, A. B. Johansson, J. H. M. Blennow, M. R. Andersson and S. M. Gubanski, IEEE Trans. Dielectr. Electr. Insul., 2013, 20, 1712-1719. 